\title{
0 pano de fundo de Apocalipse 11:1-2
}

FRANCISCO JAVIER HIGUERA ${ }^{1}$

medição do templo em Apocalipse 11:1-2 tem sido entendida de Uma das principais chaves no entendimento, tanto deste texto quanto do Apocalipse como um todo, é a alusão ao Antigo Testamento por trás da passagem. Frequentemente têm sido atribuídos dois panos de fundo do Antigo Testamento para tal imagem, no entanto, esse estudo visa esclarecer que tal conexão não é legitima na sua totalidade, mas que existe um pano de fundo daniélico na medição do templo.

Palavras chave: Alusões ao AT; Medição do templo; Apocalipse; Pano de fundo.

\section{The background of Apocalypse 11: 1-2}

The measuring of the Temple in Revelation 11: 1-2 has been 1 understood in different ways according to the different interpretive perspectives. One of the main keys to understanding both this text and the Apocalypse as a whole is the allusion to the Old Testament behind

1 Mestre em Teologia Bíblica pelo Seminário Adventista Latino-Americano de Teologia (Salt). Professor de Religião e Teologia Bíblica na Universidade Adventista do Chile. E-mail: franciscohiguera@unach.cl 
this passage. Often it has been attached two Old Testament backgrounds for the image (Zech 2:1-5 and Ezek 40-48); however, this study aims to clarify that such connection is not legitimate in its entirety, instead of it, there is a danielic background in that measuring of the temple.

Key words: OT allusions; Measuring of the temple; Revelation; Background.

\section{Introdução}

Antes de analisar um trecho do livro do Apocalipse, e por causa da caraterística apocalíptica da passagem, deve ser compreendido qual é o background por trás dele. No caso de Apocalipse 11:1-2, os eruditos mencionam duas possibilidades; a primeira é um Sitz im Leben com relação à destruição de Jerusalém no ano 70 d.C., que foi, de alguma forma, reinterpretada pelo autor do Apocalipse, que escreveu mais de 20 anos depois desses fatos terem acontecido; a segunda possibilidade de background indica que poderia haver uma alusão ao Antigo Testamento. Sendo assim, o presente estudo pretende esclarecer qual é a imagem por trás da medição do templo em Apocalipse 11:1-2, e serão analisadas uma por uma dessas principais opções.

\section{Sitz im Leben da destruição de Jerusalém}

Com respeito à origem (e originalidade) deste trecho, alguns estudiosos têm declarado que Apocalipse 11:1-2 é uma inserção baseada num texto judaico anterior. Esta hipótese começou com Wellhausen (1899, p. 222223), que seguindo seu costume de procurar fontes e tradições por trás de textos bíblicos, afirma que Apocalipse 11:1-2 corresponde a um antigo oráculo zelote anterior ao ano 70 d.C. que profetizava que, embora o pátio fosse destruído pelos romanos, o templo e quem adorasse nele seria preservado dessa destruição. ${ }^{2}$ Alguns têm assinalado que Wellhausen (1899) se baseou

2 Alguns dos eruditos que se aderem a esta teoria de forma total ou parcial são: Charles (1920, p. 270-274); Beckwith (1919, p. 586-588); Yarbro Collins (1976, p. 195); e Aune (2002b, p. 585, 594-595). Yarbro Collins (1984, p. 67) entende que, como esse 
no relato de Josephus (1996, p. 285-286), que afirma que na conquista de Jerusalém no ano 70 d.C., os líderes judeus que tinham tomado posse da cidade subornaram profetas falsos e um deles proclamou que o povo deveria se refugiar no templo (hieron) onde Deus libertaria o povo miraculosamente. Charles (1920, p. 270) endossa parcialmente a ideia e reconhece implicitamente que esta hipótese começou com Wellhausen (1899), e basicamente os que o seguiram têm construído sobre ela.

Osborne (2014, p. 469) chama a atenção para alguns problemas fundamentais com relação a esta hipótese: 1) Por que João utilizaria um oráculo que comprovou ter sido falso? Pois nem o Templo nem o altar, e menos ainda os adoradores foram preservados na destruição de Jerusalém no ano 70 d.C.; 2) Por que João utilizaria um oráculo zelote, sendo que existia tão pouca afinidade entre o cristianismo e os zelotes?

Flusser (1988, p. 391) considera tal hipótese muito improvável pelas seguintes razões: 1) É difícil de assumir a ideia de que o oráculo dissesse que a cidade iria ser conquistada pelos gentios, porém, que o templo seria resguardado; 2) Por que um panfleto zelote de uma cidade sitiada teria chegado às mãos de um profeta cristão em Patmos? 3) Mesmo se tivesse chegado, a "profecia" rapidamente teria demonstrado ser falsa. Ainda assim, para Flusser (1988, p. 391-392) o texto reflete a ideia de inviolabilidade do templo presente no judaísmo um longo tempo antes do ano em questão da invasão de Jerusalém.

O’Brien (1996, p. 198-200) também aponta para algumas das críticas que a proposta tem recebido: 1) Pela data do livro (c. 95 d.C.) seria um oráculo incompreensível; 2) A possibilidade de uma interpretação simbólica indeterminaria o significado do oráculo; 3) Traz problemas hermenêuticos pois os zelotes seriam considerados os adoradores; 4) A crença na invulnerabilidade do templo torna prescindível a existência do oráculo.

Beale (1999, p. 556) também se opõe a esta tese. Na sua visão, não há evidência da existência dessa fonte fora do Apocalipse, e mesmo que existisse, seu significado não poderia ser entendido pois não sabemos qual é o seu contexto literário e aplicação utilizada. Da mesma forma, é difícil sustentar que um profeta cristão reinterpretaria, no ano 95 d.C. da perspectiva da comunidade cristã, tais fatos que aconteceram no ano 70 d.C. com um grupo de zelotes.

suposto oráculo zelote não teve um cumprimento literal, foram procuradas outras interpretações. Já Roloff (1993, p. 129) propõe que é uma fonte cristã, não zelote. 
Além das razões mencionadas acima, existem várias outras razões para descartar essa hipótese: 1) Se baseia principalmente numa conjectura, pois tal fonte não tem sido encontrada; 2) Se baseia na pressuposição de que o templo em Apocalipse 11:1-2 se refere ao templo de Jerusalém (de Herodes); 3) Se baseia na pressuposição de que a medição do templo simboliza preservação.

Nesse ínterim, a dependência do autor do Apocalipse por parte de uma antiga fonte judaica parece ser uma mera especulação sem maior fundamento ${ }^{3}$. De qualquer forma, se a hipótese de Wellhausen (1899) e de determinados autores modernos for correta, o trecho deve ser analisado em sua forma final, de acordo com o uso que o autor faz dele (AUNE, 2002b, p. 598; YARBRO COLLINS, 1979, p. 70).

\section{Possíveis alusões veterotestamentárias}

O AT permeia completamente as imagens, o simbolismo e até mesmo a estrutura do Apocalipse, Apocalipse 11:1-2 não parece ser a exceção ${ }^{4}$. Desta forma, será necessário procurar os possíveis backgrou$n d s$ veterotestamentários para Apocalipse 11:1-2 e avaliar se eles conseguem se adequar a isso. Um aspecto importante que deve ser levado em conta é que Apocalipse 11:1-2 se encontra estreitamente relacionado

3 Caird (1966, p. 131, tradução nossa) chega a chamar tal hipótese de "improvável, inútil e absurda".

4 Sobre esse assunto existe amplo consenso do extenso uso que o autor do Apocalipse faz do AT. Swete (1907) afirma que há, no Apocalipse do NT (WESCOTT; HORT, 2008, p. 37), 278 referências às escrituras judaicas, enquanto que Ford (2008) encontra 518 citações e alusões da mesma fonte. Beale (2013, p. 55) afirma que são contabilizadas desde 394 até 1000 alusões ao AT no Apocalipse, no entanto, algumas delas possuem apenas a categoria de ecos. Para Paulien $(2009$, p. 136, 138) no entanto, existem por volta de 2000 referências ao AT de um ou outro tipo no Apocalipse, e entre $80 \%$ e $85 \%$ da sua simbologia deve ser entendida à luz das escrituras hebraicas, mas é enfático em dizer que o Apocalipse nunca cita diretamente o AT. De qualquer forma, a noção de que o Apocalipse é completamente permeado pelo AT (por sobre todos os outros livros do NT) é compartilhada por vários, senão a maioria dos autores (BAUCKHAM, 1993b, p. 18-22; BEALE; MCDONOUGH, 2007, p. 1081; CARSON; MOO, 2005, p. 712). Segundo Charles (1920, p. 66), João traduz suas alusões diretamente de um texto do AT hebraico ou aramaico, nunca cita de nenhuma versão grega, contudo, parece ter sido influenciado de certa forma por alguma dessas versões gregas. 
com as suas partes adjacentes, todavia, ele forma uma unidade em si mesmo. ${ }^{5}$ Desta forma, o pano de fundo para Apocalipse 11:1-2 deveria conseguir dar conta de todo o texto em si e não apenas de um aspecto ou uma palavra. Os panos de fundo que são identificados com maior frequência com Apocalipse 11:1-2 são Zacarias 2:1-5 e Ezequiel 40-48 (STRAND, 1984, p. 317; O’BRIEN, 1996, p. 201), no entanto, também têm sido vistos outros panos de fundo para este texto:

\section{Zacarias 2:1-5}

Uma longa lista de autores enxerga esse texto como sendo um dos panos de fundo veterotestamentários para Apocalipse 11:1-2. ${ }^{6}$ No entanto vários deles o consideram como secundário depois de Ezequiel 40-48. Outros eruditos também lhe acrescentam Zacarias 1:16 para formar esse pano de fundo (O'BRIEN, 1996, p. 201; LARONDELLE, 1997, p. 215; ROGERS, 2002, p. 104).

O texto parece descrever um anjo com um cordel na mão, o qual é enviado para medir Jerusalém e conhecer suas medidas, e logo é anunciado que Jerusalém será habitada novamente sem menção às muralhas físicas, mas afirmando que o próprio Deus se tornaria uma muralha de fogo para a cidade. $\mathrm{O}$ contexto imediato parece indicar a anterior dispersão de Judá pelas incursões das nações pagãs (1:21) e sua posterior restauração (2:10-13). Assim mesmo, parece estar subentendida a garantia da contínua proteção de Deus sobre Jerusalém (2:5), em face à tensa situação em que se encontrava a cidade por causa dos inimigos externos. ${ }^{7}$

O texto de Zacarias 2:1-5 tem sido relacionado com Apocalipse 11:12 basicamente por causa de que existe noção de medir uma estrutura física com um instrumento. Não obstante, existem enormes diferenças entre am-

5 Ver o capítulo 3 da minha tese do mestrado (HIGUERA, 2016, p. 48-53)

6 Por exemplo, Aune (2002b, p. 603); Veloso (1999, p. 146); LaRondelle (1997, p. 215); Bauckham (1993a, p. 269); Paulsen (1992, p. 280). Rogers (2002, p. 104-107) chega a apontar que Zacarias 1:16 (2:1-5) é o principal background veterotestamentário para Apocalipse 11:1-2 em vista do seguinte: 1) Menção à linha de medição em Zacarias 1:16, que, na visão de Rogers (2002), seria equivalente à vara mencionada em Apocalipse 11:1. 2. A construção da "sua casa" sugere que, segundo Rogers (2002), João estaria interpretando-a como o santuário em Apocalipse 11:1. A fragilidade dessas ligações não permite que sejam consideradas em si mesmas como conexões legítimas entre um texto e outro. 7 Ver Meyers e Meyers (2008, p. 149-157) e Baldwin (1972, p. 112-114). 
bos os textos. Em Zacarias 2:2, a medição é planejada para toda a cidade de Jerusalém, porém, em Apocalipse 11:1-2 é reduzida apenas para o templo, o altar e os adoradores. Assim mesmo, em Zacarias 2:2 é o "homem" (presumivelmente um anjo) aquele que deve executar a medição. Pelo contrário, em Apocalipse 11:1-2, o próprio João é comissionado para medir. $\mathrm{Da}$ mesma forma, o instrumento da medição é diferente. Enquanto que em Zacarias 2:1 se utiliza uma corda, em Apocalipse 11:1 o instrumento é uma cana. Sendo assim, em ambos os textos, o instrumento da medição, quem mede e o que será medido são completamente diferentes. Outra diferença em que Zacarias não parece fazer alguma referência explícita ao altar nem aos adoradores. Como parece ser, a única coisa que ambos textos têm em comum é o fato de que, em ambos os casos, existe uma medição realizada com um instrumento. Strand (1984, p. 320) aponta para o fato de que o contraste vai mais além; a medição em Zacarias não parece ser realizada, pois a cena parece se focar em retratar o cuidado e proteção de Deus.

Nesse sentido, pode ser concluído que "com exceção de um símbolo especifico, Zacarias 2:1-5 manifesta um absoluto contraste com Apocalipse 11:1" (STRAND, 1984, p. 321, tradução nossa). Contudo, talvez pela presença da medição, a ação profética de Apocalipse 11:1-2 pode estar ecoando (embora não parece ser provável) à ação profética de Zacarias 2:1-5.

\section{Ezequiel 40-48}

Uma boa parte dos eruditos identifica a grande visão final descrita em Ezequiel 40-48 (ou parte dela) como sendo o pano de fundo (geralmente o principal) para Apocalipse 11:18 em vista de que, em ambos os casos, é realizada uma medição sobre imóveis sagrados utilizando uma cana como instrumento de medir.

Na visão de Ezequiel 40-48, o profeta é levado para uma alta montanha perto da cidade santa onde se reúne com um homem (presumivelmente um anjo), ${ }^{9}$ com uma cana e uma corda na sua mão, medindo cuidadosa e detalhadamente as diferentes partes da "casa", dos átrios exteriores e das portas (40:5-49), e parece apontar que, somente no ca-

8 Dentre eles, podem ser mencionados: Mounce (1997, p. 213); Johnson (1981, p. 499) Beale e McDonough (2007, p. 1118); Thomas (1995, p. 79-80); Roloff (1993, p. 128); Paulien (2014, p. 2); Chilton (1987, p. 115); Stefanovic (2009, p. 347-348); Kistemaker (2000, p. 435); Osborne (2014, p. 462); Ford (2008, p. 175) e outros.

9 Ver TAYLOR, 1969, p. 244 
pítulo 41, ele começa a medir o templo interior em si (41:1) (ZIMMERLI, 1979, p. 342-343). Já na passagem de Ezequiel 43:1-12, o autor vê a glória de Deus entrando novamente no templo. Nos capítulos seguintes são dadas as disposições para os serviços e rituais do novo templo escatológico e do Israel restaurado. Para Stefanovic (2009, p. 347, ver 43:711), esse texto aponta para uma tentativa divina de restaurar sua relação com Israel. Allen (2002, p. 213) da mesma forma, o entende como um oráculo de salvação, no qual aquilo que afetou o reino pré-exílico de Israel e Judá não seria um obstáculo no templo e na cidade reconstruídos, uma vez que o relacionamento de Deus com seu povo foi restaurado. ${ }^{10}$

Stefanovic (2009, p. 347) e Paulien (2014, p. 2) ${ }^{11}$ afirmam que essa visão de Ezequiel ocorre em Yom Kippur, a partir de Ezequiel 40:1 (ver Lv. 23:27), que diz: "No princípio do ano, no décimo dia do mês [...]". Essa afirmação se embasa na suposição de que Ezequiel estava utilizando o calendário civil judaico, cujo começo era no outono boreal. O calendário "civil" tinha cedido seu lugar ao calendário religioso, cujo vigor começou na primeira pesach (Êx. 12:2), portanto, a dúvida aqui é se Ezequiel está se referindo ao princípio do ano do calendário civil ou do calendário religioso. Shea (2001, p. 159-160) explica que, pelo contexto da profecia de Ezequiel 40-48, esse "princípio do ano" deveria ser no outono (boreal), pois se a profecia for feita no Yom Kippur seria altamente significativa em relação ao conteúdo da visão. Seja ou não correta essa última afirmação, Shea (2001, p. 152-163) argumenta convincentemente que o calendário de outono a outono (civil) era utilizado tanto no exílio quanto em anos posteriores e anteriores. Entretanto, para Allen (2002), a declaração sobre a data da última visão de Ezequiel é ambígua podendo se referir tanto à primavera quanto ao outono (2002, p. 229. Nichol (1978a, p. 712), através

10 Existem problemas interpretativos relacionados a essa visão. Talvez a principal discussão esteja em volta da visão da qual Ezequiel 40-48 está falando do segundo templo, que obviamente pareceria uma profecia não cumprida em vista que nele não é mencionada a habitação da "glória de Deus". Além disso, existem questionamentos se ele está realmente se referindo à reconstrução do templo futuro. Taylor (1969, p. 246) observa que existem várias caraterísticas da descrição do templo que tornariam pouco provável uma interpretação literal de reconstrução. Dessa maneira, não se presume que o texto aponte para o segundo templo.

11 Considerações expressas no texto "The Facebook commentary on Revelation 11", de Jon Paulien, publicado em 2014. Disponível em: <https://bit.ly/2s1OzwB > Acesso em: 05 de mai. 2017. 
do Comentário Bíblico Adventista do Sétimo Dia, adota uma posição similar. Vanderkamp (1996, p. 817) afirma que a contagem de data após o exilio não é clara pois existe evidência tanto da contagem desde o outono quanto da primavera. Diferentemente, Fredenburg (2002, p. 357) assevera que o calendário utilizado consistentemente por Ezequiel era o calendário com início na primavera. Dessa maneira, as afirmações de Paulien (2010) e Stefanovic (2009) permanece na incerteza, todavia, se ambas forem corretas poderiam mudar o paradigma da interpretação deste texto e sua suposta função como background para Apocalipse 11:1-2.

A ampla atribuição de Ezequiel 40-48 como pano de fundo para Apocalipse 11:1-2 têm alguns detratores. Strand (1984, p. 321) percebe que, a despeito da similaridade entre os dois escritos, existem também evidentes contrastes entre ambos, dentre eles um alto número de objetos presentes na medição de Ezequiel 40-48 que não aparecem em Apocalipse 11:1-2, ou até mesmo é indicado que alguns deles não devem ser medidos (por exemplo, o pátio exterior é medido em Ez. 40:17 mas não deve ser medido em Ap. 11:1-2). Da mesma forma, nada é dito dos adoradores que também são medidos em Apocalipse 11:1-2. Todavia, o último contraste que Strand (1984) identifica entre ambos os textos é o propósito de ambas medições, enquanto que na medição de Ezequiel o propósito é prover um plano para a construção do templo e para o planejamento físico da cidade. A medição joanina parece se focar em entidades já existentes e não num sentido estritamente físico. Finalmente Strand (1984, p. 321) conclui que ambos textos são tão diferentes que dificilmente possa se estabelecer uma relação entre um e outro. ${ }^{12}$

O'Brien (1996, p. 201) chama a atenção para certos contrastes entre ambos textos (a despeito de considerar Ez. 40-42 como o background mais apropriado para Ap. 11:1-2). Ele argumenta que, enquanto que na visão de Ezequiel o foco está principalmente nas portas e no pátio, em Apocalipse 11:1-2, o pátio é excluído da medição. Além dessas diferencias já mencionadas, deve ser dito que em Ezequiel não existe uma ordem de medição, detalhe que parece ser um dos contrastes mais marcantes entre as duas visões.

Desta forma, são vistos vários contrastes entre uma visão e outra, dentre os principais estão a exclusão do pátio, a medição exclusiva do

12 Para uma defesa contra a crítica de Strand (1984) à dependência de Ezequiel 40-48 em Apocalipse 11:1-2, ver Beale (1999, p. 559). 
templo, do altar e dos adoradores e a existência de uma ordem de atuação ativa do visionário em Apocalipse 11:1-2. Tais caraterísticas contrastam esmagadoramente com Ezequiel 40-48.

Aparentemente, existe outro texto no Apocalipse que se remete à visão de Ezequiel 40-48. Bauckham (1993a, p. 269) percebe corretamente que a visão de Ezequiel 40-48 tem mais em comum com a medição da Nova Jerusalém em Apocalipse 21:15 do que com a medição em Apocalipse 11:1. Ele argumenta que, em ambos os textos, existe um paralelo com o agente da medição (o "homem" em Ez. 40 e o anjo em Ap. 21:15), contrastando com Apocalipse 11:1-2, onde é o próprio João quem deve medir. De mesmo modo, O’Brien (1996, p. 201) constata outra semelhança entre Apocalipse 21:15 e Ezequiel 40-48, ausente em Apocalipse 11:1-2, correspondente ao fato de que nos dois primeiros textos existe um foco nas portas, juntamente com o pátio exterior, o qual não acontece em Apocalipse 11:1-2. Similarmente, Aune (2002b, p. 603) aponta para outro forte paralelo entre ambas visões. Na visão de Ezequiel 40-48, o profeta é colocado num alto monte onde enxerga a cidade de Jerusalém restaurada (Ez. 40:2) e logo ele vê o homem medindo (Ez. 40:3). Paralelamente, João também é levado para um monte alto (Ap. 21:10a) onde lhe é mostrada a Nova Jerusalém (Ap. 21:10b), e logo o anjo procede a medir (Ap. 21:15-17). Do mesmo modo é evidente a projeção escatológica de restauração final de Ezequiel 40-48 (especialmente nos capítulos 47 e 48), que se encaixa melhor no capítulo 21 de Apocalipse do que no capítulo 11, e que parece estar localizado antes do clímax final.

Sumarizando, Apocalipse 21 e Ezequiel 40-48 compartilham as seguintes caraterísticas: 1) É um ser sobrenatural que realiza a medição em ambos os casos. Os profetas João e Ezequiel são espectadores meramente passivos; 2) Um dos focos da medição está nas portas e no pátio exterior; 3) Em ambos os casos o profeta é colocado num alto monte onde vê uma Jerusalém "restaurada" e logo o ser sobrenatural presente na visão começa a medir; 4) Há uma projeção escatológica de restauração final e total em ambos os textos.

Todos as semelhanças anteriores nas medições de Apocalipse 21:15 e Ezequiel 40-48 não acontecem na medição de Apocalipse 11:12. Isoladamente, o fato de que Ezequiel 40-48 seja o pano de fundo para outro texto do Apocalipse não quer dizer que não possa ser também para Apocalipse 11:1-2, no entanto, as semelhanças entre Apocalipse 11:1-2 e Ezequiel 40-48 parecem não ir além da ação da medição, da cana e do fato de que um dos elementos medidos é o templo interior. 
Considerando o que foi dito, Ezequiel 40-48 não parece se adequar bem a ser o background de Apocalipse 11:1-2, pois suas diferenças parecem falar mais alto do que as semelhanças. Da mesma forma que acontece com Zacarias 2:1-5, pode ser resgatado um eco da ação profética de Ezequiel 4048 em Apocalipse 11:1-2. Todavia, mesmo se Ezequiel 40-48 for considerado um pano de fundo para Apocalipse 11:1-2, existem suficientes trabalhos sobre essa relação, de forma que o presente estudo não entrará a fundo nele.

A consequência de adotar tanto este background quanto o anterior tem levado aos estudiosos a sugerir que o significado da medição é preservação e proteção (STRAND, 1984, p. 324); porém, tendo em vista que os dois panos de fundo já vistos não conseguem dar conta de Apocalipse 11:1-2, deveria ser buscada outra interpretação.

\section{Daniel 9:27}

Vários interpretes entendem que o período de tempo de 42 meses mencionado em Apocalipse 11:2 está aludindo ou é análogo à metade da semana (ou seja 3 1/2 dias) descrita em Daniel 9:27, ${ }^{13}$ cujo relato se encontra dentro da profecia conhecida como "as setenta semanas". Aparentemente, essa suposição se baseia em que a semana descrita em Daniel 9:27, na verdade, descreve uma semana de anos (isto é, sete anos) e, portanto, tal metade da semana em Daniel 9:27 estaria descrevendo $3 \frac{1}{1} 2$ anos, um período equivalente aos 42 meses de Apocalipse 11:2. Em favor dessa suposição, o BDB (BROWN; DRIVER; BRIGGS, 2000, p. 989) traduz a palavra Shavuim por "septeto de anos"; semelhantemente, Goldingay (2002, p. 257), assim como Hartman e Di Lella (2008, p. 244), acreditam que a tradução de "septeto de anos" seja a melhor tradução em vista dos 70 anos da profecia de Jeremias 29:10, que são indicados em Daniel 9:2, pois, aparentemente, era a esperança de Daniel que, quando tal período profetizado por Jeremias se cumprisse, a nação judia se restauraria, incluindo o templo. Por outra parte, Collins (1993, p. 353) afirma que o autor está reinterpretando a profecia de Jeremias, pois, na visão de Collins (1993), não foi entendida pelo autor como sendo cumprida com a reedificação de Jerusalém.

Todavia, não pode haver certeza dessa afirmação pois, em primeiro lugar, conforme reconhece o BDB (BROWN; DRIVER; BRIGGS, 2000, p. 988), a tradução mais comum para essa palavra é "semana" ou "septeto de

13 De acordo com Beale; McDonough (2007, p. 1118-1119); Thomas (1995, p. 84-85); Gentry (1998, p. 66); Ford (2008, p. 170); Price (1993, p. 593). 
dias". Da mesma forma, Shea (1982, p. 89-92) indica algumas das fraquezas que apresenta a pressuposição de que as semanas de Daniel 9:27-27 correspondem à semanas de anos: 1) O uso desse substantivo com a mesma soletração é consistente tanto no AT quanto em Qumran, apresentando um conceito de semana literal; 2) Em todo o AT, o substantivo shavuah é traduzido por "semana"; 3) A LXX é consistente ao traduzir em todas as ocasiões o substantivo shavuah_por ebdomas, enquanto que o número cardinal "sete" sempre é traduzido por hepta. ${ }^{14}$ Desta forma, não é possível assegurar que Daniel 9:24-27 está se referindo a "septeto de anos", ou até mesmo a um septeto sem especificar a unidade de tempo; entretanto, o seu uso mais normal é de "semana". Portanto, pelo menos do ponto de vista numérico, não parece haver paralelo nenhum entre a metade da semana de Daniel 9:27 e os 42 meses de Apocalipse 11:2.

Semelhantemente, não parece possível estabelecer algum paralelo maior entre a ação realizada em ambos os textos. Enquanto que em Daniel 9:24 se menciona que seriam destruídos tanto o templo quanto a cidade pelo povo do príncipe, em Apocalipse 11:1-2 não se menciona nada sobre a destruição do templo e da cidade.

Sendo assim, a suposta alusão de Daniel 9:24-27 em Apocalipse 11:1-2 não parece ser adequada pois não é possível assegurar que o período profético seja equivalente e, assim mesmo, o conteúdo descrito em ambas visões não parece ter maiores paralelos.

\section{Levítico 16}

O primeiro a propor este background foi Strand (1984, p. 318324), estudioso que tem sido seguido por outros scholars. ${ }^{15} \mathrm{O}$ conteúdo de Levítico 16 descreve o ritual do Dia da Expiação (Yom Kippur). Neste ritual era feita a expiação pelo sacerdote (v. 6, 11-14), pelo Santuário (v. 16-17), pelo altar (v. 18-19a) e pela congregação (v. 22).

No ritual do Yom Kippur, ${ }^{16}$ em primeiro lugar, Arão devia fazer expiação por si mesmo e pela sua casa, imolando um novilho, pegando

14 Pois o argumento é que supostamente se refere a um número indefinido de sete, podendo ser dias ou anos.

15 Alguns deles são Davidson (1991, p. 109); Paulien (1995, p. 256); Stefanovic, (2009, p. 336, 340); Treiyer (1988, p. 543.); Müller (2011, p. 443).

16 Atualmente, para muitos eruditos adeptos da hipótese documentária, as descrições deste ritual provêm de diversas fontes, as quais somente alcançariam sua forma final 
o incensário e levando o sangue do novilho para ser aspergido sete vezes acima do kapporet $^{17}$ (v. 6, 11-14), a fim de estar purificado para realizar o restante do ritual.

Uma vez concluída a expiação pelo sacerdote, o seguinte passo era fazer expiação pelo "santuário" (v. 16). Nessa etapa do ritual eram escolhidos dois bodes, um para sacrifício (o qual era para YHWH) e o outro era deixado vivo (chamado de Azazel); com o primeiro deles era realizado o mesmo procedimento que fora feito com o novilho (v. 7-10, 15).

Todavia, com respeito ao lugar que era expiado nessa parte do ritual, deve ser ressaltado que em Levítico 16:2 é indicado a Arão que ele não deve entrar em qualquer momento no qodesh, traduzido na Bíblia Almeida Revisada e Atualizada como "Santuário", e na Bíblia Nova Versão Internacional como "lugar santíssimo". Esta última parece ser a tradução mais acertada, tendo em vista que o restante do versículo indica que o lugar ao qual está sendo feita a referência é o lugar onde se encontra a arca. Milgrom (2008) optou por traduzir essa palavra como adytum, no entanto, está ciente de que se refere ao Santo dos santos (2008, p. 1013). ${ }^{18} \mathrm{Da}$ mesma forma, parece acontecer com o "santuário" (ARA) mencionado no verso 16, no qual a NVI novamente parece traduzir de maneira mais precisa, pois o contexto parece indicá-lo dessa maneira (v. 14-15).

Assim, a expiação (ou purgação) era realizada pelo Santo dos Santos por causa das impurezas (temioth), rebeliões/transgressões deles (dos filhos de Israel) (Pesha'ahim), e por "todos os pecados deles" (kol chatta'tam), os quais eram simbolicamente transferidos ao santuário tornando-o, dessa forma, poluído (HASEL, 1989a, p. 89, 93-96; MILGROM, 2008, p. 1034 $)^{19}$. Essa expiação aparentemente era completa e definitiva,

depois do exílio babilônico. Uma discussão sobre as supostas fontes está fora do propósito do presente trabalho, o qual está analisando o ritual na sua forma final.

17 Ou seja, a coberta da Arca da Aliança. Esta palavra é comumente traduzida como propiciatório. Milgrom (2008, p. 1014), entretanto, sugere que essa palavra não seja traduzida. Ver também Treiyer (1988, p. 36-37).

18 Embora seja a única ocasião onde é referida com essa palavra, nos outros lugares, o imóvel é sempre mencionado como o Santo dos Santos (2008, p. 1013). Ver Hasel (1989b, p. 112-113).

19 Gane (2005, p. 80-90) demonstra convincentemente que o objetivo principal das ofertas de purificação era remover o pecado do ofertante e transferi-lo para YHWH (por meio da imposição de mãos). Assim, era como o pagamento da dívida contraída 
apontando à eliminação total de todo tipo de pecado, o qual se demonstra por meio das palavras utilizadas no texto para diferentes tipos de "pecado" (RODRIGUEZ, 1979, p. 136; HASEL, 1989b, p. 114-115; TREIYER, 1988, p. 65). A tenda da congregação, ou seja, o lugar santo (Lv. 4:7), parecia ser expiada juntamente com o Lugar Santíssimo (v. 16b).

A próxima etapa era a purificação do altar "que está perante o Senhor" (v. 18) ${ }^{20}$, onde se colocava tanto o sangue do novilho quanto o sangue do bode nos chifres do altar, e devia ser aspergido sete vezes sobre ele (v. 18-19). Finalmente ocorria a eliminação de todas as faltas que tinham contaminado o santuário, e o processo no qual a congregação de Israel se via ritualmente livre da impureza (v. 30). Esta purgação parecia ocorrer uma vez que os pecados eram confessados por Arão, mediante imposição de mãos, sobre o bode vivo (Azazel) e ele era levado para fora da congregação (v. 20-22) (MILGROM, 2008, p. 1060; GANE, 2005, p. 136; HOLBROOK, 2012, p. 139).

De acordo com o texto de Levítico 16:33, "fará expiação pelo santuário [Lugar Santíssimo], pela tenda da congregação e pelo altar; também a fará pelos sacerdotes e por todo o povo da congregação". Um aspecto relevante do ritual como um todo é que era o única cerimônia que se focava principalmente no templo e na sua purificação, e não nos pecados do ofertante como acontecia no serviço diário (HOLBROOK, 2012, p. 135; HASEL, 1989b, p. 114; TREIYER, 1988, p. 64). ${ }^{21}$

Outra particularidade que deve ser ressaltada era o significado do dia da Expiação. Este era um dia quando toda a congregação parecia ser avalia-

pelas faltas do ofertante (representado por meio da gordura do animal) e simbolicamente o próprio YHWH era quem tomava conta dessa dívida.

20 Para Milgrom (2008, p. 1036) e Holbrook (2012, p. 139), este é o altar do holocausto. Hartley (2002, p. 240) expressa que possivelmente se refere ao altar do holocausto, e reconhece que a identificação do altar é incerta. Da mesma forma, observa que, entre os eruditos judeus, parece ser favorecida a identificação do altar de ouro, enquanto que, nos estudiosos não judeus, existe uma preferência por identificá-lo com o altar do holocausto. Treiyer (1988, p. 50) propõe que podem ser ambos altares, um no verso 18a e o outro no verso $18 \mathrm{~b}$. Hasel (1989b, p. 110), no entanto, aponta para o fato de que "altar" está no singular, e sugere que talvez seja o altar do incenso em base a Levítico 4:18, apesar de também afirmar que a expiação pela tenda da congregação possa incluir a purificação pelo altar. Ambas posições são plenamente possíveis. De qualquer forma, se a referência do verso 18 for ao altar do holocausto, Êxodo 30:10 indica que o altar de incenso também é purificado no serviço anual.

21 Treiyer (1988, p. 184) chega a afirmar que se tratava de uma vindicação do santuário. 
da. "Nesse mesmo dia, nenhuma obra fareis, porque é o Dia da Expiação, para fazer expiação por vós perante o SENHOR, vosso Deus. Porque toda alma que, nesse dia, se não afligir será eliminada do seu povo. Quem, nesse dia, fizer alguma obra, a esse eu destruirei do meio do seu povo" (Lv. 23:2830). Nesse dia, embora o foco principal estivesse no templo, o dever dos indivíduos era se arrepender dos seus pecados (WENHAM, 1979, p. 236). Holbrook (2012, p. 144-145) afirma o seguinte a respeito:

A separação entre os falsos e os verdadeiros israelitas no Dia da Expiação é um importante resultado da segunda principal ministração sacerdotal do sistema do santuário. Ambos os grupos professavam ter uma relação pactual com Deus, mas os ritos desse dia estabeleciam uma separação.

Estreitamente relacionada com esta última noção de separação e avaliação está a noção de julgamento no Yom Kippur, pois toda alma devia estar em constrição para ser avaliada durante esse dia. Quem não estava "puro" era eliminado do seu povo e, nas palavras de Wenham (1979, p. 236), era "condenado para o julgamento". Hasel (1989b, p. 120) afirma que o dia do Yom Kippur significava vida para aqueles que durante o ano "cúltico" haviam seguido apropriadamente as instruções para se livrar do pecado, da contaminação e da morte para aqueles que se recusaram a se avaliar a si mesmos por meio dos rituais de purificação e perdão de pecados. Uma ideia similar também é expressa por Gane (2005, p. 306-307), que declara que no Yom Kippur eram decididos os destinos dessas duas classes de israelitas. Tudo isso tornava o Yom Kippur o dia mais solene do calendário litúrgico judaico (SCHULTZ, 1983, p. 85).

Conforme vários estudiosos têm apontado, esses elementos que estavam envolvidos no ritual do Yom Kippur formam parte de Apocalipse 11:1-2 e, justamente na mesma ordem que aparecem em Levítico 16, onde o movimento do ritual segue o padrão: Santuário-altar-adoradores (STRAND, 1984, p. 322). A exceção é o Sumo Sacerdote. Strand (1984, p. 322) e Paulien (1995, p. 256) observam que, em vista de que no contexto neotestamentário o Sumo Sacerdote é o Jesus Cristo ressuscitado que não precisa de purificação (Hb 7:26), não há necessidade de fazer expiação por ele. Paulien (1995, p. 190) vai além ao declarar que essa referência ao santuário, altar e povo, sendo medidos, aparenta ser uma deliberada recolecção do material de Yom Kippur. Assim mesmo, este texto parece 
marcar um precedente para a linguagem cúltica do Apocalipse, pois daqui em diante começa a haver uma linguagem mais relacionada ao Yom Kippur, contrastando com os capítulos anteriores cuja linguagem estava influenciada pelos termos do tamid (STEFANOVIC, 2009, p. 34-35)

No entanto, existem críticas a essa interpretação. Osborne (2014, p. 463), Kistemaker (2000, p. 413) e O’Brien (1996, p. 207) coincidem na sua crítica ao argumento de Strand (1984) ao colocar que ele não se sustenta por causa da ausência a qualquer tipo de medição em Levítico 16. O problema dessa afirmação é que não considera todos os significados que pode ter a palavra "medição", um deles parece ser julgar ou avaliar (Mt 7:2), todavia o significado da medição será discutido em uma seção posterior.

Aune (2002b, p. 604), por sua vez, apresenta que a proposta de Strand (1984) ignora o fato de que haviam outros elementos envolvidos no ritual do Dia da Expiação, como o Santuário, a tenda da reunião, o altar, os sacerdotes e a congregação. Não obstante, o argumento de Aune (2002b) se desvanece quando analisados todos os elementos que formam parte de Apocalipse 11:1 - o santuário, o altar e a congregação se encontram em ambos textos. Os dois elementos que, segundo Aune (2002b), parecem faltar em Apocalipse 11:1 são a tenda da congregação e os sacerdotes. ${ }^{22}$

Para responder a essa pergunta, devem ser ponderadas algumas coisas. Em primeiro lugar, a purificação da tenda da congregação não era um ritual à parte, mas aparentemente era realizada como parte integrante da purificação do santuário (lugar santíssimo) (Lv. 16:16). Mesmo se fosse uma parte separada do ritual, ela parece ser limitada à purificação do altar de ouro (Êx. 30:10), pois não há menção dos outros móveis do lugar santo (HARTLEY, 2002, p. 241), e em Apocalipse 11:1 se alude tanto ao santuário/templo (lugar santíssimo), quanto ao altar. Desta maneira, o paralelo entre Levítico 16:1 e Apocalipse 11:1 não ignora a tenda da congregação que aparece no primeiro texto. Em segundo lugar, a alusão feita a Levítico 16 deve ser entendida à luz do contexto de uma comunidade cristã de final do século 1, na qual, o evento Cristo, marcava o fim de um ministério sacerdotal terrestre e o começo de um ministério sacerdotal celestial, onde o próprio Jesus era o sumo sacerdote nos céus ( $\mathrm{Hb} 4: 14$ ), e não precisa mais de oferta de purificação por ser puro e sem pecado (ver Hb 7:26-28).

22 Ver também a crítica de Mazzaferri (1989, p. 319-322). 
Desta forma, Levítico 16 parece satisfazer os critérios para ser o pano de fundo para Apocalipse 11:1. No entanto, há um problema com Apocalipse 11:2, o qual não parece refletir nenhum aspecto de Levítico 16. Desta forma, este estudo sugere que devem ser procurados outros panos de fundo, juntamente com Levítico 16.

\section{Daniel $?$}

Tem sido apontado por vários scholars um paralelo entre o Daniel 7 (especialmente Dn 7:25) e Apocalipse 11:2, principalmente por causa do período de "tempos, tempos e a metade de um tempo", que é aludido como sendo paralelo aos 42 meses referidos em Apocalipse 11:2. ${ }^{23}$ É evidente que esse período se refere a três anos e meio, ${ }^{24}$ ou seja, um período equivalente a 42 meses.

A visão de Daniel 7 apresenta quatro animais que surgem no "Grande Mar"; o primeiro como leão, o segundo como um urso, o terceiro como um leopardo e o quarto era indescritível (v. 3-7). Eles representam quatro reinos que se levantariam sobre a terra (v. 17). Do último animal surgiam dez chifres (v. 7) e, dentre eles, um chifre pequeno (v. 8) que se destacava mais do que os outros, cuja ênfase, diferentemente das quatro bestas anteriormente mencionadas (que parecem estar preocupadas com assuntos de expansão territorial), aparenta ter um foco mais religioso (SHEA, 2005, p. 117). Após essa apresentação, chega o Ancião de Dias que se assenta para julgar, e finalmente aparece como "Filho de Homem" que recebe o domínio.

A clara alusão identificada aqui se encontra principalmente na obra realizada pelo chifre pequeno, que é um ente que se levanta tanto contra o "Altíssimo" quanto contra seus santos (v. 21 e 25). O verso 25 indica que ao chifre pequeno também lhe são dados os santos por três anos e meio. Da mesma forma, Apocalipse 11:2 apresenta que o pátio que está fora do templo foi dado aos gentios, os quais pisotearão a cidade por quarenta e dois meses. Stefanovic (2009, p. 350-351) vai além ao afirmar de que o chifre pequeno de Daniel 7 e os gentios de Apocalipse 11:2 representam a mesma entidade em vista da semelhança das ações

23 Por exemplo: Aune (2002b, p. 609); Ford (2008, p. 170); Charles (1920, p. 72); Bauckham (1993a, p. 272); Müller (2011, p. 443).

24 Vários scholars têm percebido isso, dentre eles: Collins (1993, p. 322); Goldingay (2002, p. 181); Hartman e Di Lella (2008, p. 215). 
de ambos poderes, especialmente considerando-o à luz do atuar da besta que surge do mar em Apocalipse 13, a qual também oprime os santos pelo mesmo período de tempo.

Essa relação entre o chifre pequeno (Dn 7:25) e os gentios (Ap. 11:2) parece se tornar mais clara à luz do próprio texto. Ao chifre pequeno são entregues os santos do altíssimo. A palavra "entregues" (ARA) é traduzida da construção aramaica ietihabun, que se encontra no tronco verbal do hitpeel, o que confirma o passivo presente no texto. A LXX traduz essa palavra por paradothêsetai, enquanto que a versão de Teodocião traduz como dothêsetai. Em ambos os casos, o verbo corretamente se encontra no passivo. Da mesma forma, em Apocalipse 11:2 é indicado que aos gentios lhes foi dado o pátio, utilizando o passivo edothê (mesmo verbo utilizado pelo AT grego de Teodocião, e na LXX é um verbo derivado dele); o período que parece ser permitido tanto aos gentios quanto ao chifre pequeno é equivalente. No entanto, o pátio em Apocalipse 11:2 parece estar mais relacionado a elementos cúlticos do que aos "santos do altíssimo". Desta forma, esse aspecto da alusão é possível, mas não provável.

Outro argumento a favor de uma alusão a Daniel 7 em Apocalipse 11:1-2 se encontra no fato já visto de que Apocalipse 11:1 parece se referir diretamente à ênfase do juízo que vem do Yom Kippur, conforme foi argumentado na seção anterior, enquanto que em Daniel 7 existe uma clara referência ao julgamento. De acordo com o que indica o verso 10, o julgamento (dina') se assentou (ver v. 22 e 26) e o verso 26 deixa claro que o juízo realizado se reduz a favorecer apenas dos "santos do altíssimo". ${ }^{25}$ De fato, não há qualquer referência a quem não for parte desse grupo. Em Apocalipse 11:1, a medição (julgamento) é realizada apenas ao templo, altar e os que nele adoram, seguindo o padrão do julgamento realizado no Yom Kippur, que envolvia apenas os indivíduos que eram parte do povo de Deus, os quais tinham seguido as indicações prescritas durante o ano cúltico israelita, segundo foi tratado na análise do possível background de Levítico 16 para Apocalipse 11:1-2. Em suma, os dois textos concordam nesse aspecto; julgamento em favor dos santos

25 Collins (1993, p. 317-318) entende que os "santos do altíssimo" são seres celestiais, no entanto, o esclarecedor estudo de Hasel (1975, p. 173-192) parece mostrar que tal expressão não pode ser atribuída a seres celestiais. No seu lugar, ele propõe convincentemente que se refere ao povo de Deus de um ponto de vista escatológico. 
do altíssimo em Daniel 7:26 e a medição (julgamento) dos que adoram no templo em Apocalipse 11:126.

Consequentemente, conforme foi visto acima, em Daniel 7 se encontram dois elementos caraterísticos que serão utilizados pelo autor do Apocalipse: a noção de julgamento para os santos no caso de Daniel 7 que parece ser ecoado por João se referindo à medição dos adoradores, e a era profética descrita, que, em ambos os casos, é um período equivalente ( 3 anos e meio e quarenta e dois meses respectivamente), quando lhe é permitido a uma força alheia ao povo de Deus oprimir algo que é parte dele; os santos do altíssimo em Daniel 7 e o pátio em Apocalipse 11:1-2. De qualquer forma, a alusão em Apocalipse 11:1 a Daniel 7 não é completa pelo fato de que o último não descreve maiormente os elementos cúlticos presentes no primeiro (templo, altar, pátio), entretanto, o período profético citado em Apocalipse 11:2 alude claramente o período profético de Daniel 7:25 e 12:7.

\section{Daniel 8:9-14}

Em várias das sentenças de Apocalipse 11:2 têm sido percebidos certos paralelos com diferentes trechos de Daniel 8:9-14, de acordo com alguns estudiosos. ${ }^{27}$ Estes versos descrevem a obra do chifre pequeno que surge depois dos quatro chifres do bode. Conforme Hasel (1986, p. 381-382), esse chifre pequeno parece possuir duas fases, uma horizontal onde ele parece se expandir geograficamente (v. 9-10) e uma vertical (v. 11-12) onde o foco do chifre se encontra claramente no santuário celestial. ${ }^{28}$ Essa última fase retrata o chifre pequeno, que se engrandece até o príncipe do exército. $\mathrm{O}$ serviço contínuo é tirado dele ${ }^{29}$ e o fundamento

26 De fato, Baldwin (1978, p. 166) afirma que o contexto inteiro de Daniel 7 é o de julgamento como resposta à impiedade, do mesmo modo o interlúdio de Apocalipse 10:111:14 está feito em resposta à impiedade manifestada pela humanidade (Dn 9:20-21).

27 Por exemplo, Bauckham (1993a, p. 270-273); Allo (1921, p. 130); Beale, McDonough (2007, p. 1118); Mounce (1997, p. 214); Ford (2008, p. 170); Rogers (2002, p. 108); Mazzaferri (1989, p. 321).

28 Como Brasil aponta (2005, p. 453) "a presença de palavras tais como "céu", "estrelas" e "hoste celestial" no contexto indica que o "santuário" miqidash deve estar localizado no céu".

29 Versões como ARA, NVI e a NTLH acrescentam a palavra "sacrifício", no entanto, ela não se encontra no TM nem na LXX. Este estudo prefere ficar com a tradução de Hasel (1986, p. 387, 404-409) "serviço continuo". 
do seu santuário é derrubado. Em seguida, os versos 13 e 14 dizem assim: "Depois, ouvi um santo que falava; e disse outro santo àquele que falava: Até quando durará a visão do sacrifício diário e da transgressão assoladora, visão na qual é entregue o santuário e o exército, a fim de serem pisados? Ele me disse: Até duas mil e trezentas tardes e manhãs; e o santuário será purificado" (ARA).

Bauckham (1993a, p. 267) ressalta que Apocalipse 11:1-2 não tem sido compreendido completamente por causa de que essa alusão a Daniel têm sido ignorada. Ele afirma (1993a, p. 270) que ekbale "expulsa" em Apocalipse 11:2 uma tradução que João faz de Daniel 8:11 "e o lugar do seu santuário foi derrubado/expulso", e mais especificamente da palavra hushlaq "derrubado" ${ }^{30}$. Essa ideia parece encontrar o apoio pelo fato de que uma parte do serviço contínuo parecia se desenvolver no pátio que é o objeto da expulsão em Apocalipse 11:2, embora em Daniel 8:11 não pareça existir uma noção de uma profanação (HASEL, 1986, p. 410-411), ${ }^{31}$ conforme sugerido por Bauckham e por várias traduções, assim mesmo, não presume-se que este paralelo chegue a ser uma tradução.

Na mesma perspectiva, Bauckham (1993a, p. 270) argumenta que o pátio entregue aos gentios em Apocalipse 11:2 é uma alusão a Daniel 8:13: "Depois, ouvi um santo que falava; e disse outro santo àquele que falava: Até quando durará a visão do sacrifício diário e da transgressão assoladora, visão na qual é entregue o santuário e o exército, a fim de serem pisados?" (ARA). Ele o relaciona ambos textos com Daniel 12:7, que apresenta a duração do período da "destruição do povo santo", pois, para Bauckham (1993a, p. 267-268), Daniel 8:13 e 12:7 respondem à mesma pergunta: "Quanto tempo" durará a destruição do povo santo? Desta

30 Aune (2002b, p. 607) menciona algumas objeções a essa identificação, apontando que: 1) A palavra hushlaq nunca é utilizada da maneira que Bauckham (1993) pretende; e 2) ekbale se encontra na $2^{\text {a }}$ pessoa do singular do aoristo imperativo ativo descrevendo uma ação que a voz celestial ordena a João fazer, enquanto que em Daniel 8:9-14 há apenas uma descrição. Rogers (2002, p. 105) indica que, em Daniel 8, o altar de holocausto é dessolado. No entanto, em Apocalipse 11:1-2, João é comissionado a medir o altar; portanto, se houver uma alusão aqui, conclui Rogers (2002), não se sustenta pelo conteúdo ou contexto total de Daniel. Todavia, Rogers (2002) pressupõe que o Daniel 8:11 está se referindo ao fim da oferenda queimada, e que o altar em Apocalipse 11:2 é o altar de holocausto.

31 Contra Collins (1993, p. 333-334), que pressupõe que o texto se refere à contaminação do templo de Jerusalém efetuada por Antíoco IV Epifânio no século II a.C. 
forma, na ótica de Bauckham (1993a, p. 272), João interpreta o texto de Daniel e o aplica à perseguição vindoura aos cristãos. O problema dessa afirmação é que a pergunta em Daniel 8:13 não é "quanto tempo?", mas "até quando?" (HASEL, 1986, p. 433-434; BRASIL, 2005, p. 454. Ver BROWN; DRIVER; BRIGGS, 2000, p. 607). Além disso, Daniel 8:13 não está falando apenas da perseguição (Dn 8:24), mas sua ênfase parece estar nas ações do chifre contra o "fundamento" do santuário. Contudo, a alusão que Bauckham (1993a) identifica parece estar correta, apesar de seu entendimento do texto não parece ser totalmente acurado.

Entretanto, aparentemente existe um contraste entre Apocalipse 11:2 e Daniel 8:13, pois, no primeiro texto é o pátio que é entregue, contrastando com o segundo quando são entregues o "santuário" e o "exército". Todavia, há uma clara alusão pois, em ambos os casos, uma entidade é "entregue" 32 para ser pisoteada. De fato, o próprio "exército" parece ser uma referência ao povo de Deus (v. 24). Além disso, o verso 12 indica que o exército e o serviço contínuo são entregues ao chifre e, conforme já foi destacado, no pátio acontecia parte do ritual do contínuo. Desta forma, existe uma correspondência entre as entidades que são entregues aos "gentios/chifre pequeno" em Apocalipse 11:2 e Daniel 8:12-13 e 24 , respectivamente. Além do mais, deve ser levado em conta que a descrição do chifre em Daniel 8 parece ser paralela com o chifre pequeno de Daniel $7,{ }^{33}$ cujo período de ação é claramente o pano de fundo para o período em que os gentios pisam a cidade santa em Apocalipse 11:2. E esse período de Daniel 7:25 se refere justamente a uma perseguição contra os santos do altíssimo que parecem estar em paralelo com o exército (Dn 8:13) e o povo dos santos (Dn 8:24).

Conforme já foi visto, esse ato de "pisoteamento" não se refere, numa primeira instância, à profanação ou contaminação conforme comumente é acreditado, mas numa ação deliberada contra o povo de Deus, o fundamento do Santuário, contra o próprio Deus e contra sua verdade (HASEL, 1986,

32 Ambos, a LXX e Teodocião traduzem a palavra hebraica teth por dotheisa que têm a mesma raiz de edothê.

33 Assim é notado por vários autores, dentre eles: Collins (1993, p. 331) e Goldingay (2002, p. 207). Ambos autores identificam o chifre, tanto no capítulo 7 quanto no 8 , com Antíoco Epifânio. No entanto, no que concerne à ação do chifre pequeno em Daniel 8, somente a segunda fase (v. 11-12) parece estar em paralelo com o chifre pequeno de Daniel 7 (HASEL, 1986, p. 394). 
p. 428). ${ }^{34}$ Desta forma, compreendendo bem o significado da alusão, se for correta, pode ser melhor compreendido o uso que João faz desse texto.

Não obstante, existe um ponto que parece ser passado por alto quando se identifica essa alusão: a cláusula final de Daniel 8:14, "e o santuário será purificado". Em primeiro lugar, deve ser entendido que, no hebraico, a construção que a ARA traduz como "purificado" é nitsdaq, um hápax legomenon cuja raiz, segundo o BDB (BROWN; DRIVER; BRIGGS, 2000, p. 841) têm um significado primário que está relacionado a justiça. Portanto é evidente seu significado forense, pois no AT, a raiz tsadaq aponta, em várias ocasiões, para contextos judiciais (ver 2Sam 15:4; Jó 9:20; Is 41:26; 45:25) indicando que esse texto apresenta um julgamento desde o santuário (HASEL, 1986, p. 453). Por essa razão, a cláusula final de Daniel 8:14 pode ser traduzida literalmente da maneira que Brasil o faz (2005, p. 451), como "o santuário será justificado". No entanto, conforme argumentam Hasel (1986, p. 448-458), Andreasen (1986, p. 475-496) e Davidson (1996, p. 107-119), nitsadaq não pode ser restrito a um significado estreito, pois a palavra possui um campo semântico muito amplo. ${ }^{35}$ Tendo em vista a amplidão desse campo semântico, o verbo pode ser traduzido como "limpado", "vindicado", "justificado", "restaurado" (ANDREASEN, 1986, p. 494). Hasel (1986, p. 456-457) acredita corretamente que o uso que Daniel faz de nitsadaq é intencional com o intuito de apresentar esses variados aspectos da "purificação do santuário celestial".

O presente estudo pretende propor que Daniel 8:9-14 é o background direto para Apocalipse 11:1-2, incluindo a medição do templo por causa da justificação/vindicação/purificação do santuário mencionada em Daniel 8:14. A medição do templo em Apocalipse 11:1 possui um contexto judicial (DEN DULK, 2008, p. 436) ${ }^{36}$, no qual o santuário (ou

34 Na mesma página, Hasel (1986) argumenta corretamente que nenhuma das palavras usuais existem para contaminação ou impureza na descrição da ação do chifre pequeno. 35 Esses scholars argumentam que o uso da raiz daquela palavra é utilizado em paralelos verbais a outras palavras que podem significar "limpar" ou "purificar" (DAVIDSON, 1996, p. 111-112; HASEL, 1986, p. 450-451). Da mesma forma, Andreasen (1986, p. 490-491) apresenta que, em certos targuns e na LXX, frequentemente se traduzia tsidaq pela palavra que é equivalente a "purificar". Em vista desse amplo campo semântico Davidson (1996, p. 119) chega a sugerir que nitsidaq não seja traduzido. ${ }_{36}$ Pretendo escrever um artigo sobre a interpretação da Medição do Templo em Apocalipse 11:1-2 num artigo posterior. 
templo) começa a ser vindicado, da mesma forma que o santuário em Daniel 8:14 é vindicado. ${ }^{37}$ Desta forma, a justificação do santuário em Daniel 8:14 parece se encontrar em paralelo com a medição do santuário/templo em Apocalipse 11:1, pois ambas estão num contexto de julgamento envolvendo elementos cúlticos e, portanto, seriam as únicas ocasiões no Antigo e Novo Testamento nas quais o próprio santuário e os adoradores juntos são submetidos a um julgamento ou avaliação (juntamente com Lv 16).

Outro paralelo que não se deve passar por cima é o ritual que ambos textos parecem ecoar. Já foi visto anteriormente que Apocalipse 11:12 contém um evidente paralelo temático com Levítico 16, na descrição do ritual do Dia da Expiação. Hasel (1986) argumenta que Daniel 8:14 alude diretamente a esse mesmo ritual de Levítico 16, pois em ambas ocasiões se menciona a purificação do santuário ${ }^{38}$ por causa das transgressões pesha' do povo de Deus, às quais são guiadas por meio da atividade do chifre pequeno. Além disso, essa palavra contém um evidente uso cúltico-judicial..$^{39}$ Pröbstle (2006, p. 493) acrescenta que o único ritual cúltico que lidava com pesha' era o ritual do Yom Kippur descrito em Levítico 16.

Além disso, em Levítico 16 e Daniel 8:14, o termo para Santuário é qadesh. Esse uso, no último texto, não parece ser casual. Brasil (2005, p. 461) aponta que essa última forma do substantivo se encontra no verso 14 , juntamente com a "purificação" do santuário, enquanto que no verso 11 o mesmo substantivo se encontra numa construção diferente miqadash e está junto com a palavra tamid "regularidade", "contínuo". Em outras palavras, Brasil (2005) sugere que, em último caso, essa construção miqadash é utilizada para se referir aos serviços contínuos realizados no primeiro compartimento do santuário (lugar santo), enquanto que qadash aparece junto com nitsadaq "purificação/vindicação", aludindo ao serviço anual, ou seja, o Yom Kippur. Hasel (1986, p. 455, tradução nossa) chega a afirmar que: "Quando um hebreu ouvisse nitsadaq qodesh ("o santuário será purificado"), ele associaria essa função com o conceito de Dia da Expiação”. Acrescentando à claridade dessa estreita

37 Davidson (1996, p. 112-114) identifica vários paralelos verbais entre shafat "julgar", "fazer justiça" e tsidaq mostrando que dentre os múltiplos possíveis significados desse termo, o julgamento é um dos principais deles.

38 Apesar de utilizar de palavras diferentes, a noção de purificação, como já foi visto, parece estar dentro do campo semântico de nitsidaq

39 Ver por exemplo Êxodo 34:7; Números 14:18; Isaías 53:5; 59:12; Miquéias 7:18. 
ligação entre Daniel 8:14 e Levítico 16, Pröbstle (2006, p. 491) percebe corretamente que os objetos da vindicação/purificação realizada no Yom Kippur eram o santuário e o povo, os quais também são os objetos do assalto do chifre em Daniel 8. No verso 14, o objetivo é restaurar esses dois objetos chamados aqui de "santuário" e o "exército" ao seu devido lugar. Outro destaque de Pröbstle (2006) se encontra na unidade de tempo mencionada 'erev boqer "tarde-manhã", em que "tarde" vai antes do que "manhâ". Para Pröbstle (2006, p. 493), essa ordem é uma reminiscência do começo do Yom Kippur que, juntamente com a festa dos pães ázimos, era o único ritual que começava no pôr do sol (Lv 23:22). Desta forma, a conexão entre Levítico 16, o ritual do dia da expiação e Daniel 8:9-14 fica claramente estabelecida, aparentemente levando à conclusão de que a profecia de tempo descrita no verso 14 indica um Yom Kippur escatológico (PRÖBSTLE, 2006, p. 649) que iria começar quando fossem concluídas as 2300 "tardes-manhãs" (BRASIL, 2005, p. 456)..$^{40}$

Uma outra razão para sustentar o paralelo entre Apocalipse 11:1-2 e Daniel 8:9-14 se encontra no fato de que ambas aludem a Daniel 7. Conforme já foi visto na seção anterior, a obra e o período de ação dos gentios em Apocalipse 11:2 parece estar em paralelo com a obra e o período de ação do chifre pequeno de Daniel 7 (ou, na verdade, aparenta ter sido extraído dele). Da mesma forma, em Daniel 8:9-12 se apresenta a obra de um novo chifre pequeno cujas ações são semelhantes às do chifre pequeno de Daniel 7 e, segundo vários autores, esses dois chifres simbolizam a mesma entidade (COLLINS, 1993, p. 331; GOLDINGAY, 2002, p. 207). Essa relação não é artificial. Doukhan (2008a, p. 124) menciona cinco pontos de semelhança entre ambos os chifres, enquanto que Shea (1986,

40 Outras ligações entre o Yom Kippur e Daniel 8:9-14 que podem ser mencionadas são: 1) A combinação em ambos dos temas da criação, julgamento e culto (PRÖBSTLE, 2006, p. 490-491; ver DOUKHAN, 2008a, p. 129-130); 2) A totalidade dos símbolos cúlticos do Yom Kippur em todo o capítulo incluindo o carneiro, bode, e o príncipe, um termo técnico atribuído ao Sumo Sacerdote (ver Ed 8:24) (DOUKHAN, 2008a, p. 126); 3) Certa tradição rabínica liga ambos os eventos (DOUKHAN, 2008a, p. 128); 4) Tradução da LXX e de Teodocião por katharisthêsetai to hagion, "o santuário será purificado", que o relaciona diretamente com o ritual de purificação do santuário conforme acontecia no Yom Kippur; 5) Paralelo entre os serviços diários de Levítico 1-15, incluindo a poluição transferida ao santuário nos capítulos 11 e 15 e sua purgação no dia da Expiação em Levítico 16, com a sequência descrita em Daniel 8:9-14 (SHEA, 2005, p. 192-193). 
p. 187) apresenta 11 caraterísticas que eles compartilham sendo difícil não perceber ambos os chifres como sendo paralelos. Além do mais, a função da visão de Daniel 8 parece ter sido esclarecer ou ampliar a visão de Daniel 7 em vista de que, aparentemente, a última ficou inconclusa (Dn 7:28) e Daniel 8:1 começa aludindo à visão anterior de Daniel 7: "tive uma visão depois daquela que eu tivera a princípio" (ARA).

Da mesma forma, a purificação do santuário em Daniel 8:14 parece ser corretamente identificada com o julgamento em Daniel 7. Como já foi visto acima, Davidson (1996) mostra claramente a relação entre tsadiq "justificar/vindicar" e shafat "julgar". Desta maneira, ambos os verbos podem ser vistos como sinônimos. Assim mesmo, ambas as cenas parecem formar o clímax em suas respectivas visões, seguindo o mesmo padrão sequencial:

1. Bestas/animais obrando com uma ênfase horizontal (Dn 7:3-7; Dn 8:3-10)

2. Um chifre pequeno cuja ênfase é vertical, ou seja, atacando aos santos do altíssimo, no capítulo 7; exército/povo dos santos (cap. 8), o Ancião e o Filho do Homem (cap. 7); o príncipe do exército/ príncipe dos príncipes (cap. 8).

3. Cena de restauração: o Ancião de dias estabelece o julgamento (cap. 7); Purificação/vindicação do santuário (cap. 8).

4. Destruição do chifre pequeno (Dn 7:26; Dn 8:25). ${ }^{41}$

41 Esta sequência foi adaptada e comprimida de um quadro comparativo feito por Shea (1986, p. 209). Tendo em vista o espaço, não poderá ser mostrado em maiores detalhes a conexão entre os capítulos 7 e 8 de Daniel. Para maiores detalhes ver: Shea (1986, p. 183-219), Hasel (1986, p. 458-461). Menção especial ao estudo feito por Pröbstle (2006, p. 602-664) onde analisa e compara detalhadamente as semelhanças léxicas, sintáticas e temáticas entre ambos os textos, da mesma forma como identifica os contrastes entre eles. No entanto conclui que (2006, p. 663, tradução livre) “a contribuição intertextual de Dn. 7 para o entendimento de Dn. 8:9-14 é imensa”. Dentre as conclusões mais objetivas que Pröbstle (2006, p. 664) percebe, estão os chifres pequenos de ambos capítulos representando o mesmo referente e que possivelmente ambas estão apontando para um Yom Kippur escatológico. 
Concluindo de forma resumida, os paralelos que existem entre Daniel 8:9-14 e Ap. 11:1-2 são os seguintes:

1. Paralelo entre a justificação/julgamento/vindicação do santuário em Daniel 8:14 e a medição do templo em Apocalipse 11:1.

2. Clara alusão de ambos os textos ao ritual do Yom Kippur (Lv 16).

3. Clara alusão e relacionamento de ambos os textos com Daniel 7, e o seu julgamento escatológico.

4. Entrega do tamid ao chifre pequeno (Dn 8:12), paralelo com a entrega do aulê aos gentios (Ap 11:2).

5. "Pisoteamento" do exército/destruição do povo santo (Dn 8:13) paralelo ao "pisoteamento" da Cidade Santa (Ap 11:2).

Outras sugestões de panos de fundo

Alguns estudiosos têm apontado outros textos do AT, além daqueles mencionados, como o pano de fundo para Apocalipse 11:1-2. O Novo Testamente Grego percebe alusões ao "pisoteamento" da cidade em Salmo 79:1; Isaias 63:18 e Zacarias 12:3 (neste último caso, na versão da LXX). Nos dois primeiros casos não parece existir alusão em vista de que o objeto de ataque é o templo, e não a cidade, como em Apocalipse 11:2. No entanto, parece estar subentendida a noção de um ataque à cidade em Salmo 79:1b. Contudo, Apocalipse 11:2 não fala diretamente de uma profanação em contraste com o último texto. Além disso, em nenhum desses textos estão presentes, em forma alguma, os demais elementos que contêm Apocalipse 11:1-2, os quais funcionam como uma unidade indivisível, como já foi visto previamente neste estudo. No caso de Zacarias 12:3 há certas semelhanças na versão da LXX com Apocalipse 11:2. No entanto, não há qualquer semelhança com o restante do contexto de Apocalipse 11:1. Sendo assim, não parece haver maiores paralelos nessas propostas de alusões veterotestamentárias.

Jauhiainen (2002, p. 507-523) propõe Ezequiel 8:16 como o principal pano de fundo para Apocalipse 11:1-2. Ele argumenta que, no contexto veterotestamentário, a medição do templo simbolizava julga- 
mento ao povo por sua apostasia (conforme representado pela visão de Ezequiel, descrita no cap. 8, em que o profeta observa a idolatria no templo) e, como consequência, o seu templo seria destruído. No entanto, em Apocalipse 11:1, João parece estar excluindo certas partes do complexo do templo simbolizando o fato de que não haveria destruição total do novo templo na terra (na sua visão, o povo de Deus). A favor dessa identificação deve ser dito que: 1) A medição, parece denotar julgamento; e 2) Na versão da LXX de Ezequiel 8:16, se encontram a maioria das palavras chaves em grego que estão em Apocalipse 11:1-2, como nãos, thysiastêrion, proskyneô e aulê. Não obstante, não existem maiores elementos em comum em ambos os casos, pois as ações proféticas em ambos os casos não possuem maiores paralelos.

\section{Considerações Finais}

Os populares backgrounds propostos de Zacarias 2:1-5, Ezequiel 40-48 não parecem dar conta de Apocalipse 11:1-2 como um todo. A despeito da leve semelhança na imagem da ação profética executada nesses textos veterotestamentários com Apocalipse 11:1-2, os agentes, objetos e propósitos da medição são diferentes em vários aspectos, especialmente no caso de Zacarias 2:1-5. Ezequiel 40-48 parece ter maiores semelhanças, no entanto, também possui evidentes contrastes conforme foi discutido no conteúdo deste artigo. Além do mais, não parecem dar conta de Apocalipse 11:2, pois nenhuma menção é feita à totalidade de elementos que nele se descrevem. Assim mesmo, o comumente citado pano de fundo de Daniel 9:27 falha em ser o antecedente para o período de 42 meses de "pisoteamento" da cidade santa pelo fato de que não parece haver nenhuma referência direta a tal fato e o período de tempo em ambos os textos não corresponde. De qualquer forma, no caso de Zacarias 2:1-5 e Ezequiel 40-48, eles podem representar as fontes do eco que faz a ação profética realizada por João em Apocalipse 11:1-2. Contudo, no caso de Ezequiel 40-48, ele parece ter mais afinidade com Apocalipse 21 do que com Apocalipse 11:1-2.

Contudo, existe um texto que parece captar a maior parte dos elementos presentes no texto, tanto no verso 1 quanto no 2, e esse texto é Daniel 8:9-14. Tendo em vista que Apocalipse 11:1-2 é um texto que, embora esteja relacionado e é interdependente tanto das seções prece- 
dentes quanto das que o seguem, constitui uma unidade em si mesmo. Desta forma, o background para a "medição do templo" deve ter um correspondente com todo o trecho, incluindo os elementos descritos em Apocalipse 11:2. Nenhum outro texto parece captar todos os elementos descritos em Apocalipse 11:1-2 como Daniel 8:9-14 o faz. Entretanto, existem variados elementos que são extraídos de Levítico 16 e de Daniel 7. Contudo, esses elementos também parecem se encontrar presentes explicita ou implicitamente em Daniel 8:9-14, de acordo com aquilo que foi argumentado acima. Sendo assim, sobre esses três textos - Levítico 16; Daniel 7 e Daniel 8:9-14 - parece ser construída a imagem total do pano de fundo para Apocalipse 11:1-2.

\section{Referências}

ALLEN, L. Word Biblical Commentary: Ezekiel 20-48. Dallas: Word Books, 2002. v. 29.

ALLO, E. B. Saint Jean l’Apocalypse. 2. ed. Paris: Victor Lecofre, 1921.

ANDREASEN, N. E. Translation of Nisdaq/Katharisthēsetai in Daniel 8:14. In: HOLBROOK, F. (Ed.). Symposium on Daniel: introductory and exegetical studies. Washington: Biblical Research Institute, 1986.

AUNE, D. World Biblical Commentary: Revelation 6-16. Dallas: Word Book, 2002b. v. 52.

BALDWIN, J. Daniel: an introduction and commentary. Nottingham: Inter-Varsity Press, 1978. (Tyndale Old Testament Commentaries 23)

BALDWIN, J. Haggai, Zechariah and Malachi: an introduction and commentary. Notthingham: Inter-Varsity Press, 1972. (Tyndale Old Testament Commentaries 28)

BAUCKHAM, R. The Climax of Prophecy: studies on the book of Revelation. Edinburgh: T\&T Clark, 1993a.

BAUCKHAM, R. The Theology of the Book of Revelation. Cambridge: Cambridge University Press, 1993b. 
BEALE, G. The Book of Revelation: a commentary on the greek text. Grand Rapids: Eerdmans, 1999.

BEALE, G. Manual do uso do Antigo Testamento no Novo Testamento: exegese e interpretação. São Paulo: Vida Nova, 2013.

BEALE, G; MCDONOUGH, S. Revelation. In: BEALE, G; CARSON, D. Commentary on the New Testament Use of the Old Testament. Grand Rapids: Baker Academic, 2007.

BECKWITH, I. The Apocalypse of John: studies in introduction with a critical and exegetical commentary. New York: The Macmillan Company, 1919.

BRASIL, E. The Heavenly Sanctuary/Temple Motif in the Hebrew Bible: function and relationship to the earthly counterparts. Berrien Springs, 2005. Tese (Doutorado em Religião, Estudos do Antigo Testamento) - Seventh-Day Adventist Theological Seminary. Andrews University: Berrien Springs, 2005.

BROWN, F.; DRIVER, S.; BRIGGS, B. Enhanced Brown-Driver-Briggs Hebrew and English Lexicon. Oak Harbor: Logos Research System, 2000.

CAIRD, G. B. The Revelation of Saint John. Peabody: Hendrikson Publishers, 1966. (Black's New Testament Commentary)

CARSON, D.; MOO, D. An Introduction to the New Testament. 2. ed. Grand Rapids: Zondervan, 2005.

CHARLES, R. H. A Critical and Exegetical Commentary on the Revelation of St. John. Edinburgh: T\&T Clark International, 1920. v. 2.

CHILTON, D. The Days of Vengeance: an exposition of the book of Revelation. Fort Worth: Dominion Press, 1987.

COLLINS, J. Daniel: a commentary on the book of Daniel. Minneapolis: Fortress Press, 1993. (Hermeneia: A Critical and Historical Commentary on the Bible)

DAVIDSON, R. In confirmation of the sanctuary message. Journal of Adventist Theological Society. Collegedale, v. 2, n. 1, p. 93-114, 1991. 
DAVIDSON, R. The meaning of Nisdaq in Daniel 8:14. Journal of Adventist Theological Society. Collegedale, v. 7, n. 1, p. 107-119, 1996.

DOUKHAN, J. Secretos de Daniel: sabiduría y sueños de un príncipe judío en el exilio. Doral: APIA, 2008a.

FLUSSER, D. Judaism and the Origins of Christianity. Jerusalem: The Magnes Press, 1988.

FORD, J. Revelation: introduction, translation and commentary. New Haven: Yale University Press, 2008. v. 38.

FREDENBURG, B. Ezekiel. Joplin: College Press, 2002 (The College Press NIV Commentary)

GANE, R. Cult and Character: purification offerings, day of atonement and theodicy. Winona Lake: Eisenbrauns, 2005.

GENTRY, K. A Preterist view of Revelation. In: GUNDRY, S.; PATE, M. (Eds.). Four Views on the Book of Revelation. Grand Rapids: Zondervan, 1998.

GOLDINGAY, J. World Biblical Commentary: Daniel. Dallas: Word, Incorporated, 2002. v. 30.

HARTLEY, J. World Biblical Commentary: Leviticus. Dallas: Word, Incorporated, 2002. v. 4.

HARTMAN, L.; DI LELLA, A. The Book of Daniel: a new translation with notes and commentary on chapters 1-9. New Haven: Yale University Press, 2008. v. 23. (The Anchor Yale Bible Commentaries)

HASEL, G. The "Little Horn," the heavenly sanctuary and the time of the end: a study of Daniel 8:9-14. In: HOLBROOK, F. (Ed.). Symposium on Daniel: introductory and exegetical studies. Washington: Biblical Research Institute, 1986. (Daniel \& Revelation Committee Series)

HASEL, G. Studies in biblical atonement I: continual sacrifice, defilement/cleansing and sanctuary. In: WALLENKAMPF, A.; LESHER, R.; HOLBROOK, F. (Eds.). The 
Sanctuary and the Atonement: biblical, theological and historical studies. Abridged Edition. Washington: Biblical Research Institute, 1989a.

HASEL, G. Studies in biblical atonement: II day of atonement. In: WALLENKAMPF, A.; LESHER, R.; HOLBROOK, F. (Eds.). The Sanctuary and the Atonement: biblical, theological and historical studies. Abridged Edition. Washington: Biblical Research Institute, 1989b.

HOLBROOK, F. O Sacerdócio Expiatório de Jesus Cristo. Tatuí: CPB, 2012.

JOHNSON, A. Revelation. In: GAEBELIN, F. (Org.). The Expositor's Bible Commentary: Hebrews through Revelation. Grand Rapids: Zondervan Publishing House, 1981. v. 12.

JOSEPHUS, F. The wars of the Jews. In: WHISTON, W. (Ed.). The Works of Josephus: complete and unabridged. Peabody: Hendrikson, 1996.

64 KISTEMAKER, S. The temple in the Apocalypse. Journal of the Evangelical Theological Society, v. 43, n. 3, p. 433-441, 2000.

LARONDELLE, H. How to Understand the End-Time Prophecies of the Bible: the biblical-contextual approach. Sarasota: First Impressions, 1997.

MAZZAFERRI, F. The Genre of Revelation from a Source-critical Perspective. Berlin: Walter de Gruyter, 1989.

MEYERS, C.; MEYERS, E. Haggai, Zechariah 1-8: a translation with introduction and commentary. New Haven: Yale University Press, 2008. v. 25. (The Anchor Yale Bible Commentaries)

MILGROM, J. Leviticus 1-16: a new translation with introduction and commentary. New Haven: Yale University Press, 2008.v. 3. (The Anchor Yale Bible Commentaries)

MOUNCE, R. The Book of Revelation. Grand Rapids: William Eerdmans Publishing Company, 1997.

MÜLLER, E. Der Erste und der Letzte: Studiem zum Buch der Offenbarung. Frankfurt: Peter Lang, 2011. 
NICHOL, F. (Ed.). Seventh-Day Adventist Biblical Commentary. Takoma Park: RHPA, 1978a. v. 4.

O'BRIEN, K. An Examination of the Meaning, the Purpose and the Function of the Interlude within the Sevenfold series of the Book of Revelation. Richmond, 1996. 355f. Tese (Doutorado em Novo Testamento) - Union Theological Seminary. Richmond, 1996.

OSBORNE, G. Apocalipse: comentário exegético. São Paulo: Vida Nova, 2014.

PAULIEN, J. The Role of the Hebrew Cultus, Sanctuary and Temple in the plot and structure of the Book of Revelation. Andrews University Seminary Studies. Berrien Springs, v. 33, n. 2, p. 245-264, 1995.

PAULIEN, J. Seven keys: unlocking the secrets of Revelation. Nampa: PPPA, 2009.

PAULSEN, J. Sanctuary and judgement. In: HOLBROOK, F. Symposium on Revelation: book II. Hagerstown: RHPA, 1992. (Daniel and Revelation Committee Series)

PRICE, J. R. The Desecration and Restoration of the Temple as an Eschatological Motif in the Tanach, Jewish Apocalyptic Literature and the New Testament. Austin, 1993. 687f. Tese (Doutorado em Religião) - Faculty of Graduate School. University of Texas at Austin, Austin, 1993.

RODRIGUEZ, A. Substitution in the Hebrews Cultus and in Cultic-Related texts. Berrien Springs, 1979. 399f. Tese (Doutorado em Antigo Testamento) - Seventh Day Adventist Theological Seminary. Andrews University, Berrien Springs, 1979.

ROGERS, R. An Exegetical Analysis of John's Use of Zechariah in the Book of Revelation: the impact and transformation of Zechariah's text and themes in the Apocalypse. Forth Worth, 2002. 201f. Tese (Doutorado em Novo Testamento) - Southwestern Baptist Theological Seminary, Forth Worth, 2002.

ROLOFF, J. The Revelation of John: a continental commentary. Minneapolis: Fortress Press, 1993.

SCHULTZ, S. Leviticus: God among his people. Chicago: Moody Press, 1983. 
SHEA, W. Selected Studies in Prophetic Interpretation. Washington: BRI, 1982. (Daniel \& Revelation Committee Series)

SHEA, W. A review of the biblical evidence for the use of the fall-to-fall Calendar. Journal of Adventist Theological Society. Collegedale, v. 12, n. 2, p. 152-163, 2001.

SHEA, W. Daniel: a reader's guide. Nampa: Pacific Press Publishing Association, 2005.

STEFANOVIC, R. Revelation of Jesus Christ: commentary on the book of Revelation. 2. Ed. Berrien Springs: AUP, 2009.

STRAND, K. An overlooked Old-Testament background of Revelation 11:1 Andrews University Seminar Studies. Berrien Springs, v. 22, n. 3, p. 317-325, 1984.

SWETE, H. B. The Apocalypse of St. John. 2. ed. New York: The Macmillan Company, 1907.

TAYLOR, J. Ezekiel: an introduction and commentary. Nottingham: InterVarsity Press, 1969. (Tyndale Old Testament Commentaries)

THOMAS, R. Revelation 8-22: an exegetical commentary. Chicago: Moody Publishers, 1995.

TREIYER, A. El Día de la Expiación y la Purificación del Santuario: en el Pentateuco, los libros históricos, en los profetas, en Hebreos y en Apocalipsis. Florida: ACES, 1988.

VANDERKAMP, J. Calendars: ancient israelite and early jewish. In: FREEDMAN, D. Anchor Bible Dictionary. New York: Doubleday, 1996. v. 1.

VELOSO, M. Apocalipsis y el fin del mundo. Florida: ACES, 1999.

WELLHAUSEN, J. Skizzen und Vorarbeiten. Berlin: Georg Reimer, 1899.

WENHAM, G. The Book of Leviticus. Grand Rapids: Eerdmans Publishing Company, 1979. (The New International Commentary on the Old Testament) 
YARBRO COLLINS, A. The Combat Myth in the Book of Revelation. Missoula, 1976. Tese (Doutorado em Religião) - Harvard University. Missoula, 1976.

YARBRO COLLINS, A. The Apocalypse: a biblical-theological commentary. Wilmington: Michael Glazer, 1979. (New Testament Message v. 22)

YARBRO COLLINS, A. Crisis and Catharsis: the power of the Apocalypse. Philadelphia: Westminster Press, 1984.

ZIMMERLI, W. Ezekiel: a commentary on the book of the prophet Ezekiel. Philadelphia: Fortress Press, 1979. (Hermeneia: a critical and historical commentary on the Bible) 